\title{
Hospice Counsellor Facing the Grief of the Terminally III Child and Its Family
}

\begin{abstract}
The child's illness, suffering and death provoke many emotions in the family. The ill child and its family both experience grief which is an emotional reaction to the danger of losing health or life. Support offered by home hospices for children aims at overcoming the destructive influence of illness. A hospice counsellor's task is to improve the ill child and its family's quality of life. He is helping the family overcome grief and prepare for the child's death. The hospice team supports the family members who experience anticipatory and later, actual mourning. Preventing pathological effects of grief is a basic challenge for people who offer help.
\end{abstract}

\section{Keywords}

Grief, ill child, support, hospice, counsellor.

The desire for happiness of both individual family members and the family as a whole is the essence of family life. The child's smile reflects family happiness. If the child's development is proceeding, the child will feel happy. In contrast, any problems in family life will result in the feeling of grief. Illness always brings about grief, particularly if it affects a child. The duration of an illness and illness stage influence the intensity of the child's and the family's grief.

The illness does not mean that the child will not be happy again. If the family members are close to each other, they may be happy despite the serious reasons to worry about. However, numerous families, in particular those affected by the child's terminal illness, need social support which would help them to find reasons 
for happiness. One way to support family is the impact of a pedagogical focus on family system. Included in the standards of hospice help it can significantly contribute to the restoration of family peace and joy. In order to show the importance of this kind of support, it is necessary to clarify the understanding of the grief in the context of illness.

\section{The meaning of grief}

Grief is a psychological category related to human feelings: "Grief is an intense emotional state associated with the loss of someone or something with whom or with which one has had a deep emotional bond"'. The key concept here is loss. Losing somebody or something may be the cause of despondency and sorrow. Hence, the experience of grief - known to everyone is associated with mourning. In further discussion grief will be therefore understood as well as sadness, concern and worry which are frequent emotional reactions to a child's terminal illness.

Grief is commonly associated with depression, which is too far-fetched: "Great sadness, dejection and even mourning are something different from the state of serious concern or helplessness related not only to life difficulties but also conditioned by internal psychological problems. Moreover, they are something different from depressive illness, the state of upsetting many body functions in which the overwhelming change of mood is merely one of the symptoms"2. Although grief may be a symptom of depression or psychological problems ${ }^{3}$, its causes are completely different. This fact is confirmed by the clinical approach to depression, an illness which is accompanied by various states from warmth, cleanliness and meekness to dirt, cold and boisterousness ${ }^{4}$. It does not mean separating grief from the problem of depression, which may result from a terminal illness or serious troubles in life. Nevertheless, the issue of support which is required while dealing with depression goes beyond the study of pedagogical help.

${ }^{1}$ A.S. Reber, Grief, in: A.S. Reber, The Penguin Dictionary of Psychology, London 1985, Penguin Books, p. 684.

${ }^{2}$ S. Porczyk, Depresja - podstawowe informacje, in: www.online.synapsis.pl (19 III 2012).

${ }^{3}$ J. Tatarowicz: Depression, in: Encyklopedia pedagogiczna XXI w., T. Pilch (ed.), vol. 1, Warszawa 2003, Żak, p. 648.

${ }^{4}$ A. Kępiński, Melancholia, Warszawa 1974, PZWL, p. 149-152. 


\section{Grief related to the child's illness and death}

The vision of losing a close person leads to grief, which is a dynamic process: "Grief is not a state but a process. It needs not a map but a history. (...) Grief is like a long valley, a winding valley, where any bend may reveal a totally new landscape"s. Describing his personal experience of grief after his wife's death, C. S. Lewis drew attention to the process of mourning extended in time, leading to the discovery of new life perspectives which emerge from the immensity of despondency. Grief may also be caused by an illness, usually a terminal one. It is particularly intense when the illness affects a child: "A child's incurable and advancing illness entails dealing with one of the greatest losses in human life".

The possibility of losing a child is regarded by parents and healthy siblings as a great danger. However, one cannot forget that, above all, it is the ill child who has to deal with the difficult situation. Hence, a detailed analysis of the child's way of experiencing grief is needed.

\section{a/ Grief of a terminally ill child}

Grief and helplessness are the most frequent direct reactions to the child's significant needs which remain unsatisfied ${ }^{7}$. It is worth analysing both grief and helplessness as it will facilitate understanding of the young patient's situation. Although a detailed analysis is not possible here, a short presentation of the ill child's needs seems to be necessary. It will be based on Maslow's hierarchy of needs and will contain detailed remarks.

At the lower levels of Maslow's hierarchy there are deficiency, safety and belonging needs while at the higher levels there are esteem needs (self-esteem and knowledge) and self-actualisation needs (understanding of the world, aesthetics and religion $)^{8}$.

Satisfying the ill child's physiological needs tends to be postponed and has a slow pace. It is worth highlighting that the most significant of the child's needs, that is recovery from the illness, cannot be satisfied, which becomes the fundamental cause of grief. One must bear in mind the child's suffering and

\footnotetext{
${ }^{5}$ C.S. Lewis, A Grief Observed, New York 1961, Harper \& Row, p. 50.

${ }^{6}$ M. Kostek, Formy pomocy rodzinie w obliczu śmierci dziecka, in: S. Steuden, S. Tucholska (eds.) Psychologiczne aspekty doświadczenia żałoby, Lublin 2009, KUL, p. 207.

${ }^{7}$ B. Ziółkowska, Dziecko chore w domu, w szkole i u lekarza. Jak wspomagać rozwój dzieci przewlekle chorych, Gdańsk 2010, GWP, p. 63.

${ }^{8}$ H. Krzysteczko, Osobowość, in: J. Makselon (ed.) Psychologia dla teologów, Kraków 1995, PAT, p. 178-180.
} 


\section{Volume 2 (2012) Number 2}

the greatest danger to their life which is created by the vision of death ${ }^{9}$. The child is anxious about its own future as well as about the future of the rest of its family ${ }^{10}$. The child's attitude to its illness differs from the way adults experience health problems: "The child is optimistic by nature, accepts its experiences more naturally, and easily adapts to various limitations in life. In this aspect it is of help child's concrete way of thinking"'11.

Children openness to the world combined with factual thinking and strong influence of imagination on their perception of things means that sometimes the distinction between the real and imaginary world is difficult for them. Nonetheless, it does not mean that the child is not aware of its situation. The older they are, the more insistent they become about inquiring what is happening to them and what dangers are posed by their illness: "A child's cognitive and emotional understanding of illness and death is related to their developmental age, individual circumstances (including religion and culture) and life experience"12.

Children are conscious of the danger created by their illness. They feel worry which can have a positive (anticipatory) or negative influence on them ${ }^{13}$. Positive influences enable them to prepare for the end of their life. It means gradual acceptance of the loss resulting from their illness. On the contrary, pathological forms of worry intensify the lack of acceptance of their condition ${ }^{14}$. They also affect the child's other needs which remain frustrated since health problems cause constant distress.

Safety is a basic psychological need termed by Maslow as a deficiency need. Need for safety is a defense mechanism against the world surrounding the child. When the child does not get enough support, it becomes anxious about being

${ }^{9}$ The child's attitude towards pain and death goes beyond the issue of deficiency needs and its significance was only mentioned. More on this subject see: L. Szczepaniak, Troska o dziecko umierające w szpitalu. Studium z pogranicza medycyny i teologii moralnej, Kraków 2008, ITKM, p. 66-74.

${ }^{10}$ G. Godawa, Działalność hospicjów dziecięcych jako próba adekwatnej odpowiedzi na potrzeby dziecka terminalnie chorego i jego rodziny, in: Prawne, administracyjne $i$ etyczne aspekty wychowania w rodzinie, S. Bębas, E. Jasiuk (eds.), Radom 2011,WSH, p. 493.

${ }^{11}$ U. Łupińska, A. Szewczyk, Wybrane zagadnienia z opieki paliatywnej nad dziećmi, in: K. de Walden-Gałuszko, A. Kaptacz (eds.), Pielegnniarstwo w opiece hospicyjnej, Warszawa 2008, PZWL, p. 230.

${ }^{12}$ S. de Graves, J. Hynson, Family carers of children confronting life-threatening illnesses, in: Family Carers in Palliative Care. A Guide for Health and Social Care Professionals, P. Hudson, S. Payne (eds.), Oxford 2009, Oxford UP, p. 196.

${ }^{13}$ K. de Walden-Gałuszko, Problemy psychiczne, duchowe i etyczne, in: K. de WaldenGałuszko, A. Kaptacz (eds.), Pielegniarstwo..., op. cit., p. 199-200.

${ }^{14}$ Ibid., p. 200. 
lonely. Children do not comprehend the mechanism of alienation induced by their illness, which is another cause of their suffering. For the young patient, the family is the environment with which he usually identifies himself and which enables him to feel safe. The child tries to communicate with the family making use of the available communication channels. This is the case even if the only way to communicate is touch. In the family as a whole, every dysfunction intensifies the child's unpleasant feelings.

The cognitive need as well as the need for activity were also included in Maslow's hierarchy of needs. They are related to human interests ${ }^{15}$. When a healthy child wants to satisfy these needs, it plays and learns. However, when the child is ill, its inability to move freely or go to school may be detrimental to its psyche: "A child who moves too little can suffer from psychological tiredness and becomes inactive and sad. This disguises the symptoms of depressive disorder"16. If the child spends the whole day in bed, its grief seems to be justified. Limited possibilities of world exploration are also connected with the dissatisfied need for independence, crucial for a healthy adolescent. Sexual needs related to the human sphere of self-realisation are also significant. Although the majority of ill children will never fulfill their sexual needs, forming the right attitude to their own sexuality may protect them from behaviour impeding their development ${ }^{17}$.

The need to understand the world as well as the need for aesthetics and religion are at the top of Maslow's hierarchy of needs. These needs result in questioning the meaning of life. The answer is expected from doctors, parents and God. No answer either a complicated explanation makes it difficult for the young patient to understand his situation ${ }^{18}$. The emotions of the child who is unable to satisfy spiritual or religious needs seem to be particularly painful.

The vast array of the ill child's needs makes it difficult to take action aimed at fulfilling the child's needs. On the other hand, in order to initiate help, the ill children's needs should be recognised. Besides, the needs of the other family members who also have to deal with suffering should be taken into consideration.

\section{b/ Grief of the ill child's family}

The ill child's family needs to be present by the child, to receive information about the child's health and mental condition as well as to get psychological

\footnotetext{
${ }^{15}$ B. Ziółkowska, Dziecko chore..., op. cit., p. 55-57.

${ }^{16}$ Ibid., p. 119.

${ }^{17}$ G. Godawa, Działalność hospicjów..., op. cit., p. 495.

${ }^{18}$ L. Szczepaniak, Troska o dziecko..., op. cit., p. 165.
} 
support and have the opportunity to "relieve tense feelings" needs are also crucial because the parents want to provide the family with proper living conditions. The support of the family may also concern the spiritual and religious sphere of life as it helps the family to get through the difficult time. It should be emphasised that "chronic somatic illness affects not only the child's development but also the development of all other family members and of the family as a whole" 20 . Therefore, when considering the healthy family members' needs, one cannot forget that they also experience suffering which is a reflection of the child's pain. While analysing the dependence of the child on the rest of the family, it may be assumed that grief results from experiencing both anticipation of losing a child and actual loss brought about by the child's illness.

The parents' first step to accept the loss is a constructive attempt to adjust their lives because of the child's illness ${ }^{21}$.They need to accept the fact that the illness deprived the child of many forms of activity and therefore, it hindered the child's development. Such limitations frequently lead to a shift in expectations of the child as well as a change of plan concerning the child's development or education. This means handling the awareness of unfulfilled ambitions. When the parents adjust their lives because of the child's illness, their disappointment and grief are replaced by hope which makes them focus on the most effective form of helping the child.

Grief that results from the awareness of the child's approaching death is slightly different. It is defined as anticipatory mourning 22 : "Bereavement begins before the death of the patient and much can be achieved by providing help in advance" 23 . It helps the family to prepare for the child's death. Although such preparations seem to be advantageous, they are in a sense restricted as death cannot be compared to any human experience: "However much it is anticipated, death is always a profound emotional and sometimes physical shock for relatives" ${ }^{\prime 2}$. Shock after the child's death is always an extreme experience.

${ }^{19}$ K. de Walden-Gałuszko, Problemy psychiczne..., op. cit., p. 205.

${ }^{20}$ B. Ziółkowska, Dziecko chore..., op. cit., p. 73.

${ }^{21}$ A. Maciarz, Macierzyństwo w kontekście zmian społecznych, Warszawa 2004, Żak, p. 39.

${ }^{22}$ P. Krakowiak, A. Paczkowska, E. Starkel, Praca socjalna w stużbie terminalnie chorym $i$ ich bliskim $w$ opiece paliatywno-hospicyjnej, in: J. Binnebesel, A. Janowicz, P. Krakowiak, A. Paczkowska (eds.), Pozamedyczne aspekty opieki paliatywno-hospicyjnej, Gdańsk 2010, Fundacja Hospicyjna, p. 27-28.

${ }^{23}$ B. Monroe, Psychosocial Dimension of Palliation, in: D.C. Saunders, N. Sykes (eds.), Management of Terminal Malignant Disease, London 1993, Hodder Headline PLC, p. 194.

${ }^{24}$ Ibid., p. 194. 
Mourning after the child's death is in a natural way connected with grief. Close relationship between people makes the parting very painful ${ }^{25}$. Therefore, mourning affects everyone to whom the child was dear. The stages of mourning have already been thoroughly described in literature. Nonetheless, the fact that every family member experiences mourning in a different way is worth highlighting. The parents in particular have to bear the burden of mourning. They have to deal with their own pain but at the same time they cannot neglect the other children. During this difficult time they need "information, reassurance, expression of feeling, involvement and opportunities to reflect and remember" ${ }^{\prime 26}$. The attempt to meet the needs of the dead child's family is to help them overcome grief, which is possible thanks to the deep experience of mourning.

A short presentation of the needs of the ill child and their family makes it possible to indicate the forms of support which would help the family to protect themselves against the destructive influence of grief. Although satisfying all significant needs is unattainable, adequate help may effectively reduce the destructive influence of illness. One of the forms of helping the family is pedagogical support.

\section{Attempts to counteract grief on a pedagogical level}

The child's illness initiates social actions in order to overcome it. Medical support aimed at improving the patient's physical condition is the most basic level of help. The necessity of holistic help in which there is place for humanists and counsellors is more and more often emphasised ${ }^{27}$. The need for support of the ill is expressed in the following question: "If medicine tries to maintain physical well-being of the ill person, can the maintenance of psychological and social well-being not be included in the tasks of caretaking pedagogy?" 28 . The affirmative answer to this question needs to be complemented by the justification based on pedagogical principles.

${ }^{25}$ M. Keirse, Piętno smutku. Stowa otuchy dla tych, którzy cierpia, Radom 2005, POLWEN, p. 13.

${ }^{26}$ B. Monroe, Children and Bereavement, „Death and Dying” (2001) 10, p. 80.

${ }^{27}$ It is worth remembering that professor Julian Aleksandrowicz, founder of the Hematology Clinic at the Jagiellonian University Medical College in Cracow, was the forerunner of the interdisciplinary approach to the patient, in: H. Wrona-Polańska, Twórcze zmaganie się ze stresem szansa na zdrowie. Funkcjonalny Model Zdrowia osób po transplantacji szpiku kostnego, Kraków 2011, UJ, p. 11-13.

${ }^{28}$ E. Jundziłł, R. Pawłowska, Pedagog wobec osoby chorego, Gdańsk 2010, Harmonia, p. 24. 


\section{a/ Counsellor helping the ill child and its family}

The counsellor has an important role in the educational process of a healthy child. It may be assumed that his task is to lead the child ${ }^{29}$ to achieve complete development. The child's parents are the first and most important counsellors. They satisfy the child's needs and prevent deprivation of their needs. With time parents are supported by school which apart from teaching should also help form the child's personality. In other words, school should educate the child. It can be assumed that with time there are more and more people who take care of the child's education.

The educational process of the ill child usually takes place in completely different conditions. There is a possibility to take part in inclusive education but many ill children cannot study at school. One of the reasons for that is the chronic nature of the illness. The conditions of development of ill and healthy children are different but the illness does not suppress the need for the presence of a counsellor who is able to guide the child. A counsellor who is to prepare the child for death deserves the title of children's friend. He can also be called a friend of God because when he offers love to children, he shows them God's goodness.

The counsellor's role is not only limited to contacts with children and forming their attitudes. He is also responsible for contacts with the child's parents. $\mathrm{He}$ is educating them, which means "constant enrichment of parents' common knowledge about pedagogy with elements of scientific knowledge concerning education of children and adults" ${ }^{\prime 3}$. Raising the pedagogical awareness means providing the parents with knowledge about education, psychology, medicine, morality and values.

Pedagogisation of the ill child's parents may be impeded by adverse circumstances. However, professional support on the part of counsellors may help the family to care for the child's needs more effectively. It may strengthen the family thanks to taking an interest in the healthy siblings since the other children's needs tend to be marginalised. Yet, the healthy siblings also need attention and care.

${ }^{29}$ J. Mastalski, Zarys teorii wychowania, Kraków 2002, PAT, p. 14.

${ }^{30}$ S. Kawula: Pedagogisation of parents, in: Encyklopedia pedagogiczna, W. Pomykało (ed.), Warszawa 1993, Innowacja, p. 581.

The concept of pedagogisation of parents was not included in the recent edition of the encyclopedia. This idea was partly substituted by the concept of educating adults. One may observe that the concept of pedagogisationis being gradually forgotten in the field of pedagogy. This topic is further discussed in B. Pawlak'sbook Jak współpracować z rodzicami uczniów klas początkowych?, Kraków 2003, AP, p. 81-82. 
Pedagogical support for the ill child and their family may be offered in hospita ${ }^{31}$ and at home. Home hospices for children are one of the innovative ways of supporting the ill child and their family.

\section{b. Counteracting grief in hospice environment}

Hospices are usually associated with grief which is inseparable from the children's terminal illness and their death. It needs to be emphasised that the aim of hospices is to make children 'smile till the end' ${ }^{32}$ rather than to wait for their death. Hospice workers take a systematic approach to the family and offer holistic help ${ }^{33}$. This assumption is reflected in the following model: "care for the whole person, and their family, with a multidisciplinary team"34. Hospices care for both the ill child and their family. Therefore, in a multidisciplinary team there are doctors, nurses, psychologists, physiotherapists, social workers and a chaplain. There are also counsellors whose role is very important since they are responsible for educating the child.

The creativity of the counsellor creates an opportunity to satisfy the child's cognitive needs and to make the child more active ${ }^{35}$. The counsellor frequently plays with the child which enables them not only to explore the world but also to relieve stress. Playing is also a source of happiness and therefore, it becomes an antidote for worry. Moreover, it has therapeutic effects as it makes the child get used to difficult situations (e.g. playing 'patients and doctors') and relieves tension $^{36}$. It also contributes to changing of the child's reluctant attitude towards medical staff ${ }^{37}$.

Plush toys are also an important tool in the counsellor's work with children. They make younger children feel safe. At the same time, they teach how to satisfy material needs. Plush toys are observed to become confidants of children's emotions and secrets. Therefore, personifying them as friends and the possibility to confide in them help the child to articulate their feelings. Playing is also a way to fill the child's free time. Thanks to the counsellor's visits time is properly used.

Not all children in hospices are able to study or play. Some children are sometimes excluded from these kinds of activity because of their illness.

\footnotetext{
${ }^{31}$ S. de Graves, J. Hynson, Family Carers..., op. cit., p. 204-205.

${ }^{32}$ www.almaspei.pl (20 III 2012).

${ }^{33}$ P. Krakowiak, A. Paczkowska, E. Starkel, Praca socjalna ..., op. cit., p. 13-18.

${ }^{34}$ M. Ashby, D. Mendelson, Family Carers: Ethical and Legal Issues, in: Family Carers...,

${ }^{35}$ G. Godawa, Działalność hospicjów..., op. cit., p. 501-502.

${ }^{36}$ B. Ziółkowska, Dziecko chore..., op. cit., p. 133-141.

${ }^{37}$ E. Jundziłł, R. Pawłowska, Pedagog wobec..., op. cit., p. 66.
} op. cit., p. 94-95. 


\section{The Person and the Challenges \\ 118 Volume 2 (2012) Number 2}

However, if there is a chance to make use of the senses, the child should be ensured pleasure and joy. If visual or auditory contact with the child is possible, it is advisable to make use of staging which is of great spiritual and therapeutic significance. Volunteers can help in preparing these activities.

The counsellor's presence in the ill child's house creates the possibility to take an interest in healthy siblings who also have to cope with their brother's or sister's illness ${ }^{38}$. Parents who care for the ill child often do not pay enough attention to the other children who may have learning difficulties. Hence, there is a need to boost the other children's self-esteem and to set the educational process in the right direction. Discreet yet active presence of a hospice counsellor may effectively help both children and parents.

The moment of the child's death is an unusual situation for a family to be in. If the hospice counsellor is accepted by parents and if the child trusts him, he may help the family to overcome the difficulties which are connected with the approaching death. One of the counsellor's tasks is to help the child in giving farewell to the family in the form of a letter, drawing or poem ${ }^{39}$. The counsellor may also support the family in the time of the child's agony.

Pedagogical support offered to the family before the child's death - which is a traumatic event - is to help them to experience anticipatory mourning. However, only the child's death and actual mourning show that the family needs support of the hospice team. The counsellor's help in this difficult time is aimed at the other children who according to their perceptual abilities need to know what happened to their sibling and what death is all about. Fear and grief $^{40}$ are frequent emotional reactions to a sibling's death. Counteracting pathological forms of mourning consists in offering them adequate support because the loss of a close person has negative consequences for the physical health. Support offered to the family may help reduce these effects. If we enable the child to feel safe, they will show an astonishing ability to accept the inevitability of death and to return to normal life $\mathrm{fl}^{41}$.

The aim of the pedagogical activity is to support the children so that they could go back to normal life after their sibling's death. One of the main obstacles in implementing it is grief. It is a natural reaction to death but on the other hand, it poses the danger of constant dejection. There is also another danger arousing

${ }^{38}$ J. Binnebesel, Psychopedagogiczna opieka nad rodzeństwem dziecka ,hospicyjnego”, in: Chore dziecko - chora rodzina. Materiaty konferencyjne, Gdańsk 2010, p. 6-9.

${ }^{39}$ M. Herbert, Żałoba $w$ rodzinie. Jak pomóc cierpiacym dzieciom i ich rodzinom, Gdańsk 2005, GWP, p. 25.

${ }^{40}$ Ibid., p. 49.

${ }^{41}$ Ibid., p. 53. 
from grief because the tendency to escape it is more and more visible. The family is suggested to break all the bonds with the deceased and in this way, free themselves from painful memories. One may reject all external forms of mourning but it should be emphasized that "normal life does not mean forgetting about the people we loved"42. Pedagogical support of the dead child's siblings enables them to regain the feeling of safety. It does not mean negating painful experiences but accepting the parting and discovering further life perspectives.

It should be stressed that the counsellor who is supporting the family should be discreet, sensitive, compassionate and willing to help. The activity of a hospice team aims at supporting the parents so that they could perform their roles better rather than replacing them. Therefore, any counselling activity should be subordinated to the family's well-being. Support offered by the counselor may also be related to pedagogisation which means not so much one-way information about the child's upbringing but the counsellor's willingness to cooperate. If the counsellor discusses the child's needs with their parents, it may bring new forms of care and education as well as new ways of implementing them. When the child's condition is worsening, the counselor may be given more responsibility for the healthy siblings and in case of the child's death the counsellor's presence by them will be advisable. This kind of assistance in which the degree of help is suited to the family's needs is typical for hospice activity.

\section{Conclusion}

The child's illness, suffering and death cause a lot of emotions in the family. The ill child and its family both experience grief which is an emotional reaction to the danger of losing health or life. Feeling of great grief is not easy to overcome and help does not always prove effective. However, the more effective the help is, the greater the chance to restore peace in the family with an ill child is.

Social support is the response to unsatisfied human needs. When the child is ill, these needs are focused on understanding the reason of suffering but include all other needs as well. Hence, while offering help to the ill child, one must remember about the pedagogical influence which is aimed at forming the child's personality. It may be implemented by the parents and counsellors who are helping the family. Support in a home hospice for children relates to the presence of a counsellor whose task is to improve the ill child and its family's quality of life.

\footnotetext{
${ }^{42}$ E. Jundziłł, R. Pawłowska, Pedagog wobec..., op. cit., p. 40.
} 
The counsellor has to become a significant person for the child. In order to prepare them for death, the counsellor must earn the child's trust and be convincing. It requires courage to confront the vision of his own death, the ability to work in stress and readiness for mourning after the child's death. The paradox of the hospice's help is a constant attempt to overcome the child's grief while bearing in mind that after the child's death, grief will dominate for a period of time in the family's life. However, the awareness of each child's restored smile gives great satisfaction and hope that after the child's death the time of peace will come although it will be preceded by difficult mourning.

In view of the above analysis, it appears that the aim of the pedagogical influence on the ill child and their family does not mean eradicating grief. Such emotions always accompany suffering and indicate that the bonds in the family are tight. However, reducing its impact in order to prevent its pathological effects is a basic challenge for people who offer help.

\section{Bibliography}

Ashby M., Mendelson D., Family Carers: Ethical and Legal Issues, in: P. Hudson, S. Payne (eds.), Family Carers in Palliative Care. A Guide for Health and Social Care Professionals, Oxford 2009, Oxford UP, p. 93-111.

Graves S. de, Hynson J., Family Carers of Children Confronting Life-threatening Illnesses, in: Herbert M., Żałoba w rodzinie. Jak pomóc cierpiacym dzieciom i ich rodzinom, Gdańsk 2005, GWP.

Hudson P., Payne S. (eds.), Family Carers in Palliative Care. A Guide for Health and Social Care Professionals, Oxford 2009, Oxford UP, p. 191-210.

Jundziłł E., Pawłowska R., Pedagog wobec osoby chorego, Gdańsk 2010, Harmonia.

Kostek M., Formy pomocy rodzinie w obliczu śmierci dziecka, in: S. Steuden, S. Tucholska (eds.), Psychologiczne aspekty doświadczenia żałoby, Lublin 2009, KUL, p. 207-219.

Lewis, C. S., A Grief Observed, New York 1961, Harper \& Row.

Łupińska U., Szewczyk A., Wybrane zagadnienia z opieki paliatywnej nad dziećmi, in: K. de Walden-Gałuszko, A. Kaptacz (eds.), Pielegniarstwo w opiece hospicyjnej, Warszawa 2008, PZWL, p. 230-236.

Maciarz A., Macierzyństwo w kontekście zmian spolecznych, Warszawa 2004, Żak.

Monroe B., Children and bereavement, „Death and Dying” (2001) 10, p. 76-88.

Monroe B., Psychosocial Dimension of Palliation, in: D.C. Saunders, N. Sykes (eds.), Management of Terminal Malignant Disease, London 1993, Wyd. Hodder Headline PLC, p. 174-201.

Reber Arthur S., The Penguin Dictionary of Psychology, London 1985, Penguin Books. 
Steuden S., Tucholska S. (eds.), Psychologiczne aspekty doświadczenia żałoby, Lublin 2009, KUL.

Szczepaniak L., Troska o dziecko umierajace w szpitalu. Studium z pogranicza medycyny i teologii moralnej, Kraków 2008, ITKM.

Ziółkowska B., Dziecko chore $w$ domu, w szkole $i$ u lekarza. Jak wspomagać rozwój dzieci przewlekle chorych, Gdańsk 2010, GWP. 
